\title{
Micronucleus in oral exfoliated cells and associated factors among young adults in the far south of Brazil
}

\section{Micronúcleo en células exfoliadas orales y factores asociados en jóvenes adultos en el extremo sur de Brasil}

\author{
Merlyn dos Santos Maidana ${ }^{1}$ (D) Marina dos Santos ${ }^{1}$ \\ Caroline Lopes Feijo Fernandes ${ }^{1}$ (D), Edariane Menestrino Garcia ${ }^{2}$ \\ Samuel de Carvalho Dumith ${ }^{1}$ (D) Flávio Manoel Rodrigues da Silva Júnior ${ }^{1,2 *}$ (D) \\ ${ }^{1}$ Universidade Federal do Rio Grande, Faculdade de Medicina, Programa de \\ Pós-graduação em Ciências da Saúde. Rio Grande, RS, Brazil. \\ 2 Universidade Federal do Rio Grande, Instituto de Ciências Biológicas, \\ Centro Regional de Estudos, Prevenção e Recuperação de Dependentes \\ Químicos - CENPRE. Rio Grande, RS, Brazil.
}

Corresponding author: f.m.r.silvajunior@gmail.com

\begin{abstract}
There is an increasing interest in the application of micronucleus (MN) assays in the clinical setting to investing the impact of environmental, genetic, life style and socioeconomic conditions on DNA. However, the evaluation of mutagenic damage among young population had not been studied and early intervention in this population can prevent several health comorbidities. Thus, the present study aimed in investigate the MN presence in young adults and its associated factors. This is a cross-sectional study, composed by 155 young adults (between 18 to < 30-year-old) of both sexes. The socioeconomic and life style data was collected through a semistructured questionnaire. Oral exfoliated cells were collected to evaluate the frequency of MN cells. Socioeconomic conditions and life style factors were not associated with the presence of MN. Twenty percent of the participants reported some chronic noncommunicable disease and almost twelve percent reports continued use of medication, both variables present a risk factor to prevalence of MN. Although mutagenesis is a process generally more related to older individuals, this study highlights the importance of monitored DNA damage between young adults and promote healthy habits to prevent the development and worse prognosis of chronic nontransmissible diseases and the consequent use of drugs.
\end{abstract}


Keywords: Micronucleus assay, DNA damage, biomarker, young adults.

Resumen: Existe un interés creciente en la aplicación de ensayos de micronúcleos ( $\mathrm{MN})$ en el entorno clínico para invertir el impacto de las condiciones ambientales, genéticas, de estilo de vida y socioeconómicas en el ADN. Sin embargo, no se ha estudiado la evaluación del daño mutagénico en población joven y la intervención temprana en esta población puede prevenir varias comorbilidades de salud. Así, el presente estudio tuvo como objetivo investigar la presencia de MN en adultos jóvenes y sus factores asociados. Se trata de un estudio transversal, compuesto por 155 adultos jóvenes (entre 18 y $<30$ años) de ambos sexos. Los datos socioeconómicos y de estilo de vida se recopilaron mediante un cuestionario semiestructurado. Se recolectaron células exfoliadas orales para evaluar la frecuencia de células MN. Las condiciones socioeconómicas y los factores del estilo de vida no se asociaron con la presencia de MN. El veinte por ciento de los participantes reportó alguna enfermedad crónica no transmisible y casi doce por ciento reportaron uso continuado de medicación, ambas variables presentan un factor de riesgo para la prevalencia de NM. Si bien la mutagénesis es un proceso generalmente más relacionado con las personas mayores, este estudio destaca la importancia de monitorear el daño del ADN entre los adultos jóvenes y promover hábitos saludables para prevenir el desarrollo y peor pronóstico de enfermedades crónicas no transmisibles y el consecuente uso de medicamentos.

Palabras clave: ensayo de micronúcleos, daño al ADN, biomarcador, adultos jóvenes.

\section{INTRODUCTION}

Human genetic integrity is increasingly threatened by environmental exposure to genotoxins and pollutants, lifestyle factors such dietary intake, alcohol drinking, smoking, drugs and stress, and genetic factors, e.g. inherited defects in DNA metabolism and/or repair(1-5). In addition, socioeconomic may also be associated with mutagenic damage ${ }^{(6)}$.

There are many different approaches and techniques developed for the monitoring of human genome. Since the 1980s micronucleus (MN) test on exfoliated cells of the oral mucosa has been used for the biomonitoring of humans. MN test has become the standard technique for the evaluation of cytogenetic damage in tissue targeted $(7,8)$. Therefore, there are a significant growth in the number of studies on the MN test over the years and it has been used traditionally to investigate lifestyle factors on DNA(2,6,9,10).

Santos Maidana M, Santos M, Fernandes CLF, Garcia EM, Dumith SC, Silva Júnior FMR, Micronucleus in oral exfoliated cells and associated factors among young adults in the far south of Brazil 
The most commonly used cells in MN test are lymphocytes, followed by buccal cells due the greater MN formation in these tissues. The oral mucosa is one of the most easily accessible epithelial tissues in humans and is highly relevant biomarkers of DNA damage( ${ }^{(8)}$. Moreover, the MN assay in rapid replication tissue as the oral mucosa is a technique that can be used to detect recent acute and chronic exposures $n$ the most exposure scenario $^{(2,11)}$.

There is increasing interest in the application of MN assays in the clinical setting because of their association with the live style factors ${ }^{(11)}$ and the risk of developing diseases ${ }^{(8)}$. Micronuclei (MN) appear in cytoplasm of daughter cells as small additional nuclei and contain whole chromosomes or acrocentric chromosome fragments, left behind during nuclear division. Higher MN frequency reflects chromosomal damage and may thus provide a marker for cancer risk, neurodegenerative and cardiovascular disease ${ }^{(4,12,13)}$.

Aging effect negatively DNA repair mechanisms and cytosolic DNA removal, with a steady build-up of DNA damage, increasing chronic proinflammatory signals and reactive oxygen and nitrogen species (RONS) production, increasing induction of chromosomal lesions, including MN, leading into a vicious cycle where $\mathrm{MN}$ induces inflammation and inflammation induces MN. Thus, the most of studies target older population, while, studies that evaluated with young population have been restricted to environment or occupational exposure groups ${ }^{(14-18)}$, being neglected the mutagenic damage risks on young populations. Therefore, the present study aimed in investigate the MN presence in young adults and its associated factors in a population residing in the extreme south of Brazil.

\section{METHODOLOGY}

\subsection{Individuals and sampling}

This is a cross-sectional study, composed by 155 young adults (between 18 to $<30$-year-old) of both sexes, who were attending a higher-level course in the Federal University of Rio Grande during the period between March and November 2016. Socioeconomic and life style data were collected by a semistructured, self-administered, and anonymous questionnaire. The instrument used was adapted for the university setting(19) from a validated instrument and suggested by the WHO to identify the prevalence of drug use $^{(20)}$, such as, frequency and time of use (last 30 days). Socioeconomic level were evaluated according to $\mathrm{ABEP}(21)$.

This research respected the ethical precepts recommended by Resolution 466/2012 of the National Health Council of the Ministry of Health, which

Santos Maidana M, Santos M, Fernandes CLF, Garcia EM, Dumith SC, Silva Júnior FMR, Micronucleus in oral exfoliated cells and associated factors among young adults in the far south of Brazil 
regulates research involving humans. Thus, the present study was submitted to the Research Ethics Committee in the Health Area of the Federal University of Rio Grande (CEPAS/FURG) obtaining approval through opinion no. 195/2015. Consent was obtained from all participants after the objectives, methodology, benefits, and risks of the study were explained.

\subsection{Oral exfoliated cells collection}

The collection of oral mucosa cells was performed through a smear on both sides of participants' cheek mucosa using a polyethylene brush, before the participants rinsed the mouth with free alcohol mouthwash. After the material was collected, the brush was inserted into Falcon tube containing $10 \mathrm{ml}$ of physiological saline solution $(0.9 \%)$, then it was transported to the laboratory in dark and under refrigeration.

\subsection{Micronucleus test}

The micronucleus test in oral mucosal cells was performed according to methods published by Tolbert et al (22). For slide preparation, the samples were centrifuged for 10 minutes at $1000 \mathrm{rpm}$, the supernatant was removed, and the pellet was homogenized. Approximately $1 \mathrm{~mL}$ of the sample was collected with a Pasteur pipette and placed on the slides in duplicate. After drying at room temperature, the slides were fixed with methanol for 10 minutes and then stained with eosin and methylene blue according to Leishmann.

To evaluate MN, 1000 cells were counted on the Olympus optical microscope model CX41 with a magnification of 400X and the MN number was counted following the suggestions of Holland et al.(6). Were considered for MN counting only cells with intact cytoplasm and relatively flat cell position on the slide, little or no overlap with adjacent cells, little or no debris and nucleus normal and intact with nuclear perimeter smooth and distinct. To identify $\mathrm{MN}$ the criteria were: to contain a rounded smooth perimeter suggestive of a membrane, less than a third the diameter of the associated nucleus, but large enough to discern shape and color, staining intensity similar to that of the nucleus, texture similar to that of nucleus, same focal plane as nucleus and absence of overlap with, or bridge to, the nucleus.

\subsection{Statistical Analysis}

The questionnaires were typed per double typing in Epi-Data 3.4 Software. The presence data ( 1 or more MN in 1000 counted cells) and absence (0 MN

Santos Maidana M, Santos M, Fernandes CLF, Garcia EM, Dumith SC, Silva Júnior FMR, Micronucleus in oral exfoliated cells and associated factors among young adults in the far south of Brazil 
in 1000 counted cells) of micronuclei and the frequency of MN per 1000 cells were considered for association analysis. The association between the variables and the presence or absence of MN was performed using Fisher's Exact Test or Chi-square test while the differences between MN frequency were tested using Mann Whitney test or Kruskal-Wallis test followed by Dunns test.Poisson regression with robust variance analysis was used to evaluate risk and protective factors associated with outcomes (presence or absence of micronuclei). Results were reported as prevalence ratio (PR) and $95 \%$ CI. The tests were performed with a $5 \%$ significance threshold. The data were analyzed by STATA software, version 11.2.

\section{RESULTS}

The most of participants were female (55.1\%), self-reported white skin color (74.2\%), had less than 25 years old (85\%) and were single $(94.2 \%)$ (Table 1). The distribution of participants among economic classes was homogeneous and the mean income was approximately \$346.54. Regarding life style, the most of them used to drink coffee or mate tea $(67.7 \%)$. Majority of students used illicit drugs (64.5\%) (launches perfume, ecstasy, "shoe glue", marijuana, cocaine and crack cocaine), did not smoke (79.4\%) and more than a half report used to drink alcohol (72.3\%) at last 30 days. Regarding health conditions, $20 \%$ of the participants reported some chronic noncommunicable disease, such as, epilepsy, chronic gastritis, respiratory diseases (asthma, rhinitis, and sinusitis), cardiovascular diseases, thyroid dysfunction. The continuous use of medications was reported by $11.6 \%$ of the sample. Regarding socioeconomic conditions and life style factors, only chronic noncommunicable diseases and use of medication were associated with the presence of $M N(p=0.003$ and $p=0.002$, respectively). Regarding the frequency of NM, none of the studied variables had any statistical difference.

The results of the Poisson regression analysis with robust variance are described in Table 2. Only chronic disease and use of medication were statistic significant in bivariate analysis $(\mathrm{p}=0.002)$. While, in multivariate analysis individuals with chronic disease had $20 \%$ higher risk of present MN $(p=0.03)$ and use of medication loss its statistic significant, presenting a limitrophe risk. The others variables investigated did not present significant a risk to $\mathrm{MN}$ presence and for this reason they were not presented.

Santos Maidana M, Santos M, Fernandes CLF, Garcia EM, Dumith SC, Silva Júnior FMR, Micronucleus in oral exfoliated cells and associated factors among young adults in the far south of Brazil 
Table 1. Socioeconomic and lifestyle conditions prevalence and association with MN frequency and presence/absence

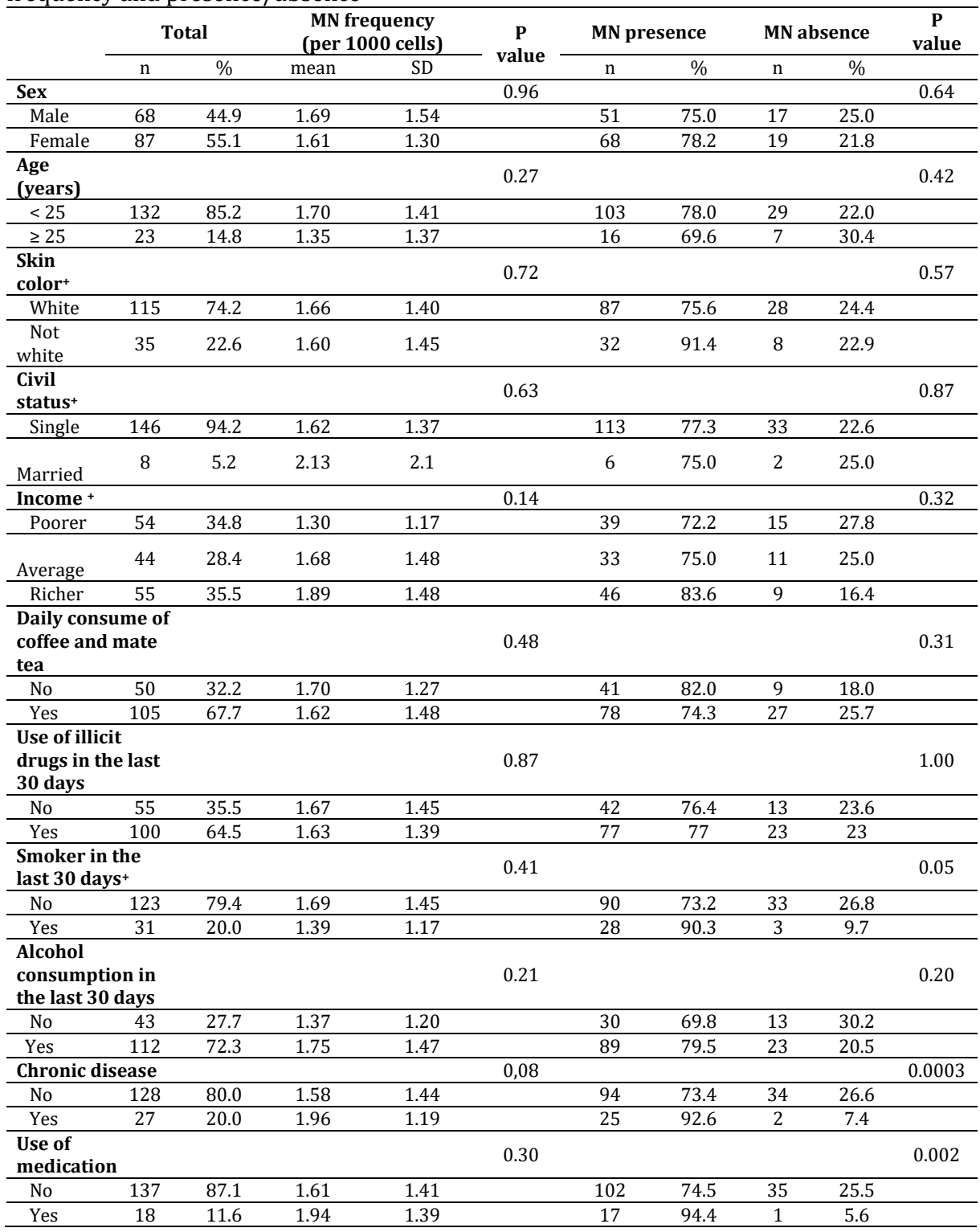

+ Some variables had lost information; skin color was the variable with more lost information (5 lost information).

Santos Maidana M, Santos M, Fernandes CLF, Garcia EM, Dumith SC, Silva Júnior FMR, Micronucleus in oral exfoliated cells and associated factors among young adults in the far south 
Table 2. Crude and adjusted analysis of the relationship between the presence of MN and the statistically significant variables

\begin{tabular}{lcccc}
\hline & $\begin{array}{c}\text { Crude (PR) } \\
\text { IC (95\%) }\end{array}$ & P value & $\begin{array}{c}\text { Adjusted (PR) } \\
\text { IC (95\%) }\end{array}$ & P value \\
\hline $\begin{array}{l}\text { Chronic } \\
\text { disease }\end{array}$ & & 0.002 & & 0.03 \\
$\quad$ No & 1 & & 1 & \\
$\quad$ Yes & $1.26(1.09-1.46)$ & & $1.20(1.02-1.42)$ & \\
\hline $\begin{array}{l}\text { Use of } \\
\text { medication }\end{array}$ & & 0.002 & & 0.05 \\
$\quad$ No & 1 & & 1 & \\
$\quad$ Yes & $1.27(1.09-1.47)$ & & $1.18(1.00-1.39)$ & \\
\hline
\end{tabular}

\section{DISCUSSION}

This study observed that between these young adults, socioeconomic conditions and life style were not associated with the presence of MN. However, these factors were important determinants of healthy behaviors and consequently had important impact on cell damage ${ }^{(22)}$. The frequency of MN found in the present study is considered within the normal range of 0.5 to $2.5 \mathrm{MN}$ per 1000 cells $^{(6)}$.

There are a feel studies that reported MN in young adults. Aging in humans appears to be associated with genetic instability, due the decline in the efficiency of repair processes and accumulation of mutations, which results in increased level of DNA damage(23). Although, the high prevalence of MN frequency among young adults evaluated in this study, there was no statistic significant difference between individuals aging less or more than 25 years old. In addition, sex may also influence in DNA damage. However, this relation seems to be less clear than others factors.

In general, studies with similar population evaluate MN frequency and the exposure to tobacco, alcohol, and other $\operatorname{drugs}(7,24,25)$. The most of these studies report significant higher MN frequency between alcoholics and these rates were even higher when individuals were smokers and alcoholics ${ }^{(7,25)}$. In this study, although, smokers had higher MN frequency, the statistical significance was limitrophe. In the past years, smoking is recognized as major risk factor for genotoxicity in oral mucosa ${ }^{(9)}$.

The World Drug Report estimate that 5.6\% of adults use illicit drug. In approximately 3 months of drug exposure the MN frequency can increase $0.16^{(26)}$. In addition, MN test was previously proved to be a good biomarker to assess the mutagenic impact among drug users ${ }^{(27)}$. Although, the most of 
study population used some illicit drug, it was not observed differences between MN frequency.

This study found that non-transmissible chronic diseases and continuous use of medication were associated with the presence of $\mathrm{MN}$, with this second variable associated and influenced by the first one. All individuals who had a chronic non-transmissible disease and continuously used medication exhibited the presence of MN in their oral mucosa cells. Several non-transmissible chronic diseases can alter the levels of oxidative stress, substance release and enzymatic activity resulting in DNA damage processes, and the use of drugs may potentiate the damage index caused by these dieses(28,29).

Corroborant to these results, there are many studies that found an association between MN frequencies and several diseases, such as autoimmune, cardiovascular and neurodegenerative dieses (13) and certain types of cancer(11). In addition, $\mathrm{MN}$ increases with the severity, exacerbations, and co-morbidity. Therefore, this study highlights the importance of evaluate NCD in young population to prevent worse outcomes in the development of the disease, since with aging there are an unbalance in antioxidant/oxidant status and insufficient DNA repair, as well as, accumulated DNA damage in cells and organs.

Medication can be used in different situations to eventually or chronic therapeutic. However, there are several young people thar use inadequately, by their known as "self-medication". This practice represents a risk to human health, due its potential toxicity(30). Self-medication is associated with different factors such as: sex, age, marital status, children, drug use, knowledge about medications and medication availability (31,32). It is important to investigate the use of medication in researches among young adults, due its possible impact on DNA integrity ${ }^{(33-35) .}$

Studies related to genome stability are not an easy task. They can be biased by many confounding factors and present low statistical strength that enable a direct attribution of the examined factors. In addition, it is often difficult to determine the causality of the MN induction(13) or if significant results found were a consequence of the medication or a biomarker of the disease. Therefore, important, that future studies investigate, in welldesigned and adequately powered studies, the prospective association of MN formation with non-c-diseases and medication use.

Santos Maidana M, Santos M, Fernandes CLF, Garcia EM, Dumith SC, Silva Júnior FMR, Micronucleus in oral exfoliated cells and associated factors among young adults in the far south of Brazil 


\section{CONCLUSION}

This study concludes that non-communicable chronic diseases and the use of continuous medication are risk factors in the population of young people studied. Furthermore, this study highlights the importance of monitored DNA damage between young adults and promote health education to prevent the development and worse prognosis of chronic non-transmissible diseases. Additionally, aware this population about the harms of "selfmedication"

\section{ACKNOWLEDGEMENTS}

This study was financed in part by the Coordenação de Aperfeiçoamento de Pessoal de Nível Superior - Brasil (CAPES) - Finance Code 001 and Conselho Nacional de Desenvolvimento Científico e Tecnológico (CNPq) 310856/2020-5.

\section{AUTHOR CONTRIBUTIONS}

MSM was responsible for designing the research project and organizing the data collection logistics; MS was responsible for all steps of building the database; CLFF and EMG were responsible for analyzing the genotoxic damage; SCD was responsible for data analysis; FMRSJ was the study supervisor. All authors contributed and approved the final text.

\section{INTEREST CONFLICT}

The authors declare no conflict of interest.

\section{BIBLIOGRAPHIC REFERENCES}

1. Pinto EADS, Garcia EM, De Almeida KA, Fernandes CFL, Tavella RA, Soares MCF, et al. Genotoxicity in adult residents in mineral coal region-a cross-sectional study. Environ Sci Pollut Res. 2017;24(20):16806-14. Available in: https://doi.org/10.1007/s11356017-9312-y

2. Bonassi S, Coskun E, Ceppi M, Lando C, Bolognesi C, Burgaz S, et al. The HUman MicroNucleus project on eXfoLiated buccal cells (HUMNXL): The role of life-style, host factors, occupational exposures, health status, and assay protocol. Mutation Research - Reviews in Mutation Research. 2011;728(3):88-97. Available in: https://doi.org/10.1016/j.mrrev.2011.06. 005

3. da Silva Júnior FMR, Tavella RA, Fernandes CLF, Soares MCF, de Almeida KA, Garcia EM, et al. Genotoxicity in Brazilian coal miners and its

Santos Maidana M, Santos M, Fernandes CLF, Garcia EM, Dumith SC, Silva Júnior FMR, Micronucleus in oral exfoliated cells and associated factors among young adults in the far south of Brazil 
associated factors. Hum Exp Toxicol. 2018;37(9):891-900. Available in: https://doi.org/10.1177/0960327117745692

4. Huang P, Huang B, Weng H, Nakayama K, Morimoto K. Effects of lifestyle on micronuclei frequency in human lymphocytes in Japanese hard-metal workers. Prev Med (Baltim) [Internet]. 2009;48(4):383-8. Available from: http://dx.doi.org/10.1016/j.ypmed.2008.12.023

5. Maidana MS, Junior ASV, Corcini CD, Pereira JR, Pires DM, Tavella RA, Fernandes CLF, Dos Santos M, Garcia EM, da Silva Júnior, F. M. R. Oral cytological changes in young adults related to alcohol consumption. Archives of Oral Biology, 2021;126, 105127. Available in: https://doi.org/10.1016/j.archoralbio.2021.105127

6. Holland N, Bolognesi C, Kirsch-Volders M, Bonassi S, Zeiger E, Knasmueller $\mathrm{S}$, et al. The micronucleus assay in human buccal cells as a tool for biomonitoring DNA damage: The HUMN project perspective on current status and knowledge gaps. Mutation Research - Reviews in Mutation Research. 2008; 659(1-2):93-108. Available in: https://doi.org/10.1016/j.mrrev.2008.03.007

7. Faria LEM, Jacqueline Ramos Machado Braga. Aplicação Do Teste De Micronúcleo Para Epitélio Oral De Estudantes Universitários. Rev eletronica Atualiza Saúde. 2015;1(1):35-41.

8. Fenech M, Knasmueller S, Bolognesi C, Holland N, Bonassi S, KirschVolders M. Micronuclei as biomarkers of DNA damage, aneuploidy, inducers of chromosomal hypermutation and as sources of proinflammatory DNA in humans. Mutat Res - Rev Mutat Res [Internet]. 2020;786:108342. Available from: https://doi.org/10.1016/j.mrrev. 2020.108342

9. Benvindo-Souza M, Assis RA, Oliveira EAS, Borges RE, Santos LR de S. The micronucleus test for the oral mucosa: global trends and new questions. Environ Sci Pollut Res. 2017;24(36):27724-30. Available in: https://doi.org/10.1007/s11356-017-0727-2

10. Bolognesi C, Bonassi S, Knasmueller S, Fenech M, Bruzzone M, Lando C, et al. Clinical application of micronucleus test in exfoliated buccal cells: A systematic review and metanalysis. Mutat Res - Rev Mutat Res [Internet]. 2015;766:20-31. Available from: http://dx.doi.org/10.1016/j.mrrev. 2015.07.002

11. Sommer S, Buraczewska I, Kruszewski M. Micronucleus assay: The state of art, and future directions. Int J Mol Sci. 2020;21(4):7-9. Available in: https://doi.org/10.3390/ijms21041534

12. Kirsch-Volders M, Elhajouji A, Cundari E, Van Hummelen P. The in vitro micronucleus test: A multi-endpoint assay to detect simultaneously mitotic delay, apoptosis, chromosome breakage, chromosome loss and non-disjunction. Mutat Res - Genet Toxicol Environ Mutagen. 
1997;392(1-2):19-30. Available in: https://doi.org/10.1016/S01651218(97)00042-6

13. Kirsch-Volders M, Bolognesi C, Ceppi M, Bruzzone M, Fenech M. Micronuclei, inflammation and auto-immune disease. Mutat Res - Rev Mutat Res. 2020;786:108335. Available in: https://doi.org/10.1016/j. mrrev.2020.108335

14. Bauer LO, Ceballos NA. Neural and genetic correlates of binge drinking among college women. Biol Psychol. 2014;97:43-48. Available in: https://doi.org/10.1016/j.biopsycho.2014.01.005

15. Aslantürk ÖS, Așkin Çelik T. Genotoxic risk assessment in professionals working hairdressers area using buccal micronucleus assay, in Aydın City, Turkey. Environ Sci Pollut Res. 2017; 24(17), 14700-14705. Available in: https://doi.org/10.1007/s11356-017-9075-5

16. Kunst LR, Garcia MV, Machado AK, Barbisan F, Silveira AF da. Otoacoustic emissions and biomarkers of oxidative stress in students of a tobacco-producing region. CoDAS. 2014;26(3):219-225. Available in: https://doi.org/10.1590/2317-1782/201420140489

17. Da Silva Júnior FMRD, Tavella RA, Fernandes CLF, Mortola AS, Peraza GG, Garcia, E. M. Genotoxic risk in health-care professionals occupationally exposed to low doses of ionizing radiation. Toxicology and Industrial Health, 2020;36(5), 356-370. Available in: https://doi.org/10.1177/ 0748233720932081

18. Da Silva Júnior FMR, Tavella RA, Fernandes, CLF, Dos Santos M. Genetic damage in coal and uranium miners. Mutation Research/Genetic Toxicology and Environmental Mutagenesis, 2021;866,503348. Available in: https://doi.org/10.1016/j.mrgentox.2021.503348

19. Maidana MS, Fernandes CLF, Dumith SC, Da Silva Júnior FMR. Prevalence and factors associated to the use of illicit drugs and psychotropic medications among brazilian undergraduates. Acta Scientiarum. Health Sciences, 2020;42,e46774-e46774. Available in: https://doi.org/ 10.4025/actascihealthsci.v42i1.46774

20. Smart RG, Hughes PH, Johnson LD. A methodology for student drug-use surveys. World Health Organization Offset Publication. 1980.

21. ABEP. Critério Padrão de Classificação Econômica Brasil. From http//www.abep.org/codigosguias/Criterio_Brasil_2008.pdf. 2008;

22. Tolbert PE, Shy CM, Allen JW. Micronuclei and other nuclear anomalies in buccal smears: methods development. Mutat Res/ Environ Mutagenesis. 1992;271(1):69-77. Available in: https://doi.org/10.1016/ 0165-1161(92)90033-I

23. Hopf NB, Danuser B, Bolognesi C, Wild P. Age related micronuclei frequency ranges in buccal and nasal cells in a healthy population. 
Environ Res [Internet]. 2020;180(October 2019):108824. Available from: https://doi.org/10.1016/j.envres.2019.108824

24. He JL, Jin LF, Jin HY. Detection of cytogenetic effects in peripheral lymphocytes of students exposed to formaldehyde with cytokinesisblocked micronucleus assay. Biomed Environ Sci. 1998; 11(1):87-92.

25. Kern R. Avaliação de micronucleos em células epiteliais bucais de estudantes de odontologia. UNIVERSIDADE ESTADUAL DE PONTA GROSSA; 2006.

26. Lorenzoni DC, Pinheiro LP, Nascimento HS, Menegar-do CS, Silva RG, Bautz WG, et al. Could formaldehyde induce mutagenic and cytotoxic effects in buccal epithelial cells during anatomy classes? Med Oral Patol Oral Cir Bucal. 2017;22(1)e58-e63. Available in: https://doi.org/ $10.4317 /$ medoral.21492

27. Tavella RA, dos Santos M, da Silveira Tatiane B, Fernandes CLF, Da Silva Júnior FMR. Micronucleus in exfoliated buccal cells of crack users: systematic review and meta-analysis. Acta Toxicol argentina. 2020;28(2):36-44. Available in: http://www.scielo.org.ar/ scielo.php?pid=S1851-37432020000200036\&script=sci_arttext\&tlng=en

28. Seven A, Güzel S, Aslan M, Hamuryudan V. Lipid, protein, DNA oxidation and antioxidant status in rheumatoid arthritis. Clin Biochem. 2008;41(78):538-543. Available in: https://doi.org/10.1016/j.clinbiochem. 2008.01.029

29. Zimnol A, Amann K, Mandel P, Hartmann C, Schupp N. Angiotensin II type 1a receptor-deficient mice develop angiotensin II-induced oxidative stress and DNA damage without blood pressure increase. Am J Physiol Physiol. 2017;316(6):F264-F273. Available in: https://doi.org/10.1152/ ajprenal.00183.2017

30. Loyola Filho AI de, Uchoa E, Guerra HL, Firmo JOA, Lima-Costa MF. Prevalência e fatores associados à automedicação: resultados do projeto Bambuí. Rev Saude Publica. 2002;36(1):55-62 Available in: https://doi.org/10.1590/S0034-89102002000100009

31. Corrêa Da Silva MG, Soares MCF, Muccillo-Baisch AL. Self-medication in university students from the city of Rio Grande, Brazil. BMC Public Health. 2012;12(1):339. Available in: https://doi.org/10.1186/14712458-12-339

32. Wagner GA, De Andrade AG. The use of alcohol, tobacco and other drugs among Brazilian college students . Uso álcool, Tab e outras Drog entre Estud Univ Bras. 2008;35(SUPPL. 1):48-54. Available in: https://doi.org/10.1590/S0101-60832008000700011

33. Brambilla G, Martelli A. Genotoxicity and carcinogenicity studies of analgesics, anti-inflammatory drugs and antipyretics. Pharmacological 
Research. 2009;60(1):1-17. Available in: https://doi.org/10.1016/ j.phrs.2009.03.007

34. Norizadeh Tazehkand $M$, Topaktas $M$. The in vitro genotoxic and cytotoxic effects of remeron on human peripheral blood lymphocytes. Drug Chem Toxicol. 2015;38(3):266-71. Available in: https://doi.org/10.3109/01480545.2014.947425

35. Lee H-C, Chiu W-C, Wang T-N, Liao Y-T, Chien I-C, Lee Y, et al. Antidepressants and colorectal cancer: A population-based nested casecontrol study. J Affect Disord. 2017;207:353-358. Available in: https://doi.org/10.1016/j.jad.2016.09.057 